\title{
Early Communicative Skills of Children with Normal Hearing and Hearing Loss Depending on Chronological and Hearing Ages
}

\author{
Ji-yeong Yun ${ }^{a}$, Hye-jin Park ${ }^{b}$, Eun-sung Lee ${ }^{a}$, Hee-soon Yoo ${ }^{a}$, Jin-sook Kim ${ }^{c}$ \\ ${ }^{a}$ Department of Speech Pathology and Audiology, Graduate School, Hallym University, Chuncheon, Korea \\ ${ }^{b}$ Department of Otolaryngology, Asan Medical Center, Seoul, Korea \\ 'Division of Speech Pathology and Audiology, Research Institute of Audiology and Speech Pathology, College of Natural Sciences, Hallym University, \\ Chuncheon, Korea
}

Correspondence: Jin-sook Kim, PhD Division of Speech Pathology and Audiology, Research Institute of Audiology and Speech Pathology, College of Natural Sciences, Hallym University, 1 Hallymdaehak-gil, Chuncheon 24252 Korea

Tel: $+82-332482213$

Fax: +82-33-256-3240

E-mail: jskim@hallym.ac.kr

Received: April 4, 2020

Revised: April 29, 2020

Accepted: May 1, 2020

\begin{abstract}
Objectives: The evaluation of speech and language is crucial for children with normal hearing $(\mathrm{NH})$ and hearing loss $(\mathrm{HL})$. The aim of this study was to investigate the early communicative skills of children with $\mathrm{NH}$ and $\mathrm{HL}$ and to compare the performance depending on chronological age (CA) and hearing age (HA). Methods: Four tools, Korean MacArthur-Bates Communicative Development Inventories (K M-B CDI), Sequenced Language Scale for Infants (SELSI), Communication and Symbolic Behavior Scales Developmental Profile (CSBS DP) checklist and behavior sample were used. The data was collected from 50 children, 26 $\mathrm{NH}$ and $24 \mathrm{HL}$ from 4 to 56 months of age. The average age of $\mathrm{NH}$ and $\mathrm{HL}$ groups was between 17- and 19-months-old, respectively. The HA of the HL group was 13-months-old. They were tested every two to three months. The developmental progress was analyzed by CA and HA. Results: With KM-B CDI, when CA and HA were compared for the HL group, the production of expressive language did not show any difference, but the receptive language and action-gesture scores were significantly better in HA at 7-9 months and 19-24 months. With SELSI, both receptive and expressive languages showed significantly better scores in HA $\left(F_{(1,73)}=0.580, p<.05, F_{(1,73)}=11.036, p<.05\right)$. With CSBS DP, the HA showed significantly better social scores for checklist $\left(F_{(1,63)}=6.248, p<.05\right)$. Conclusion: As the HA of the $\mathrm{HL}$ group showed superior performance compared to the corresponding age of the $\mathrm{NH}$ group even in the early stage, the effectiveness of HA following fitting of amplification device and the appropriate intervention has been implicated.
\end{abstract}

Keywords: Hearing loss, Early communicative skills, Hearing age, Chronological age
The language developmental process should not be overlooked in early childhood because early communicative skills are crucial for later speech and language development. The most interpersonal interactions for developing early communicative skills occur through spoken signals, but having hearing loss (HL) can hamper children in receiving these signals and limit their ability to develop early communicative skills (Knoors \& Marschark, 2014). Besides, fundamental language, social and cognitive skills are essential for normal development in early age. But lack of informal and formal learning with social-emotional, psychopathological, and cognitive difficulties would also impede the normal development of children with HL (Theunissen et al., 2014). Previous studies reported that verbal skills were directly related to the degree of HL. Therefore, evaluating communicative ability is essential for estimating the difficulties in the everyday life of children with HL, and for setting up the specific targets for providing intervention as early as 
possible (Yoon, 2007). Although assessing speech and language development of children with HL is challenging due to limited attention spans and less comprehension of communicative skills, it is important to figure out children's current levels and specifically defected areas of communication in order to build effective intervening strategies (Soman, Kan, \& Tharpe, 2012).

Many standardized evaluation tools that can examine the early communicative skills of children with HL have been introduced. For example, to obtain credible information on children's language development; including early comprehension and production of words and phrases, gesture use, and grammar, the MacArthurBates Communicative Development Inventories (M-B CDI) was developed (Fenson, Marchman, Thal, Dale, \& Reznick, 2007). It was oriented for children 8 to 30 months old and can be applied through reports from parents or caregivers who are familiar with their children. The Korean version of M-B CDI was also introduced in 2011 (Pae \& Kwak, 2011) and has been used in several studies for children of various ages (Yang, Park, Hong, Lee, \& Yim, 2019; Ha \& Pi, 2018; Choi \& Lee, 2018). For assessing communication and symbolic progress and measuring prelinguistic skills of children whose functional communication age was under 24 months, the Communication and Symbolic Behavior Scales: Developmental Profile (CSBS DP) checklist and behavior sample was developed (Wetherby \& Prizant, 2002). The CSBS DP checklist includes screening questions that can be answered by parents or caregivers for 6to 24-month-old children and the CSBS DP behavior sample includes communication-behavior evaluation materials that can be carried out by experts in a play situation for children 12- to 24-monthsold. The CSBS DP tests have been used in Korea since 2018 as the translated version was published and it was revealed to be a valid and reliable tool for assessing the early social communication skills of Korean toddlers as well (Lee, Lee, \& Choi, 2018). Furthermore, several materials examining the Korean language developmental process were invented. To screen and monitor young children with developmental delays, the Sequenced Language Scale for Infants (SELSI) was developed (Kim, Kim, Yoon, \& Kim, 2003) examining general aspects of receptive and expressive language from 4 to 35 months. It is recommended that the testing process should be carried out by primary caregivers who know the developmental process of the child in detail.
The chronological age or calendar age (CA) is a record of the time elapsed since birth which is calculated by subtracting the date of birth from the date of the test. Most of the developmental evaluation tools use CA. Another age concept for assessing children with HL is the hearing age (HA). The criteria of HA reflects the period of hearing sounds with the help of amplification devices such as hearing aids, bone-anchored implants, and/or cochlear implants. As situational and systematic intervention usually follows right after fitting the device, HA should be included in the intervention process as well. Although the usage of this concept is meaningful in children with severe and profound HL, it should be applied to all children who use amplification devices, especially in the early developmental stage. Their communication ability after they can hear the sound appropriately for developing communicative skills will certainly be very different from that of beforehand (Northern \& Downs, 2002).

There are several kinds of structured early intervention programs for children with HL. However, the developed intervention programs could not be directly applied to Korean children because of linguistic and cultural differences. The recently developed Korean Auditory, language, and cognitive Rehabilitation for Infants (KARI) was applied as an intervention program for children with HL for this study (Kim \& Yoon, 2016). It is based on five main principles which accommodate the unique family-centered Korean fostering style; including the Korean Infant Vocal and Articulate Development (KIVAD) list which organizes the developmental level of vocalization and articulation of normal children for setting a baseline and a goal for the intervention program (Kim, Yoon, Park, Park, \& Lee, 2017), 'dan-dong-sib-hoon' which is an adaptation of traditional Korean disciplinary methods for children, an attachment-parenting method emphasizing physical affection based on emotional closeness and frequent physical contact (Yoo \& Kim, 2018), a systematic modeling method, 'Short Fun Input for Modeling' for improving the effectiveness of imitation by offering simple words and giving sufficient time to emulate the stimuli, and the technique of Auditory Verbal Therapy (AVT) for emphasizing speech and listening in the natural listening environment. The KARI program is composed of the evaluation materials, parent education and counseling materials, and professional guidelines. KARI is utilized as it was developed for hearing-impaired infants 
and toddlers from 1 month old. The principle, method, and effect of KARI is beyond the scope of this paper. Further information can be found in recent publications (Kim \& Yoon, 2016; Yoo, Kim, \& Kim, 2019). Also, fitting amplification devices is considered to be a part of the intervention process. Applying for a weekly intervention program in a natural environment and helping parents to intervene on a daily basis through parent education and counseling are also included.

The purpose of this study was to investigate the specified developmental process of early communicative skills in Korean children with $\mathrm{NH}$ and HL considering the age definitions of CA and HA. In order to define the effects of evaluation of CA and HA, the developmental progress and the communicative skills of children with HL were evaluated using the K M-B CDI, SELSI, and CSBS DP checklist and behavior sample.

\section{METHODS}

50 children, 26 with $\mathrm{NH}$ and 24 with HL, 22 boys and 28 girls, ranging in age from 4 to 56 months were recruited. The average age of the NH group was 17-months-old with a range of 6 to 24 months. The average age of the HL group was 19-months-old with a range of 4 to 56 months in CA and 13-months-old with the range of 1 to 23 months in HA. All the participants were divided into six groups over a 3 month period. As a longitudinal study, the data points for each age group were as follows: In the 4-6 month group, there were a total of 24 children, with 3 children with $\mathrm{NH}$, and 21 with HL. In the 7-9 month group, there were a total of 29 children, with 10 children with $\mathrm{NH}$ and 19 with HL. In the 10-12 month group, there were a total of 19 children with 9 children with $\mathrm{NH}$ and 10 with HL. In the 13-15 month group, there were a total of 23 children, with 16 with $\mathrm{NH}$ and 7 with HL. In the 16-18 month group, there were 22 children, with 13 with $\mathrm{NH}$ and 9 with HL. And finally, in the 19-24 month group, there were 35 children, 22 with $\mathrm{NH}$ and 13 with HL (Table 1). The participants were regularly evaluated with four evaluation tools every two or three months from July 2015 to March 2019.

The HL group detected their hearing impairment through newborn hearing screening and no infant was recorded as having a premature birth. Out of the 24 HL children, 3 exhibited a magni-
Table 1. Data points for each age group of normal hearing (NH), hearing loss $(\mathrm{HL})$ with chronological age $(\mathrm{CA})$ and hearing age $(\mathrm{HA})$

\begin{tabular}{lcrrrrr}
\hline & $4-6$ mo & $7-9$ mo & $10-12$ mo & $13-15$ mo & $16-18$ mo & $19-24$ mo \\
\hline $\mathrm{NH}$ & 3 & 10 & 9 & 16 & 13 & 22 \\
$\mathrm{HL}$ & & & & & & \\
$\mathrm{CA}$ & 10 & 12 & 7 & 4 & 6 & 11 \\
$\mathrm{HA}$ & 11 & 7 & 3 & 3 & 3 & 2 \\
Total & 24 & 29 & 19 & 23 & 22 & 35 \\
\hline
\end{tabular}

mo= months.

tude of mild HL, 3 moderate HL, 4 moderate to severe HL, 6 severe HL, and 8 had profound HL based on the result of auditory brainstem response. The average hearing level was $72.6 \mathrm{~dB}(\mathrm{SD}=$ 23.6). The children with HL started to use amplification devices 9 months after birth on average and started intervention with the device simultaneously. 1 child wore a hearing aid in one ear and a cochlear implant in the other ear, 18 children wore hearing aids for both ears, 2 children wore cochlear implants for both ears, and 3 children did not have any amplification device (Table 2). All the processes were performed in a natural environment as the investigator visited the participant's home for intervention and evaluation. For the children with HL, the KARI intervention program was provided to each child 22 times, on average once a week from July 2015 to March 2019 to improve their communicative skills including counseling and education for parents and caregivers.

The selected four standardized evaluation materials, K M-B CDI, SELSI, CSBS DP checklist and behavior sample were performed. With the exception of the CSBS DP behavior sample, the three materials reflected parents' reports. The K M-B CDI assessed children's developmental outcomes in terms of comprehension and production of words and phrases, gesture use, and early grammar. The SELSI evaluated the language abilities in receptive and expressive languages for 14 age groups: 4-5, 6-7, 8-9, 10-11, 12-13, 14-15, 16-17, 18-19, 20-21, 22-23, 24-26, 27-29, 30-32, and 33-35 months. A total of 56 questions; four different questions depending on their developmental stage per each age group, were composed of receptive and expressive language. The CSBS DP checklist and behavior sample evaluated social, speech, and symbolic abilities. The CSBS DP checklist included 45 questions for assessing eye gaze, intended communication behaviors, vocalization, word production and comprehension, and playing with objects. The CSBS DP behavior 
Table 2. Description of the degree of hearing loss $(\mathrm{HL})$, date of birth, date of switch-on, age at implantation or fitting, and hearing devices of the $\mathrm{HL}$ participants and gender, date of birth, and date of beginning assessment of the normal hearing (NH) participants. The chronological age was calculated by the date of birth for both $\mathrm{HL}$ and $\mathrm{NH}$ groups and the hearing age $(\mathrm{HA})$ was calculated by the date of switch on of amplification devices or beginning date of intervention which was indicated as the asterisk $\left({ }^{*}\right)$

\begin{tabular}{|c|c|c|c|c|c|c|c|c|}
\hline \multirow[b]{2}{*}{ No. } & \multicolumn{5}{|c|}{ Hearing loss participants } & \multicolumn{3}{|c|}{ Normal hearing participants } \\
\hline & Degree of $\mathrm{HL}$ & Date of birth & $\begin{array}{c}\text { Date of switch-on } \\
\text { of } \mathrm{HA} / \mathrm{Cl}(\mathrm{HA})\end{array}$ & $\begin{array}{l}\text { Age at implantation or } \\
\text { fitting (month.day) }\end{array}$ & $\begin{array}{l}\text { Hearing devices } \\
\text { (R/L) }\end{array}$ & Gender & Date of birth & $\begin{array}{l}\text { Date of beginning } \\
\text { intervention }\end{array}$ \\
\hline 1 & Moderate to severe & 2016-11-30 & 2017-04-08 & 4.8 & $\mathrm{HA} / \mathrm{HA}$ & M & $2014-04-26$ & 2016-02-01 \\
\hline 2 & Moderate to severe & 2016-07-02 & 2017-01-13 & 6.11 & $\mathrm{HA} / \mathrm{HA}$ & $F$ & 2014-10-02 & $2015-10-14$ \\
\hline 3 & Moderate to severe & 2016-04-13 & 2016-11-09 & 6.26 & $\mathrm{HA} / \mathrm{HA}$ & M & $2014-07-27$ & 2015-09-14 \\
\hline 4 & Severe & 2016-01-05 & 2016-08-18 & 7.3 & $\mathrm{HA} / \mathrm{HA}$ & $\mathrm{F}$ & 2014-10-08 & $2015-10-26$ \\
\hline 5 & Mild & 2015-01-05 & 2016-01-15 & 12.1 & $\mathrm{HA} / \mathrm{HA}$ & $F$ & 2015-06-19 & $2015-12-29$ \\
\hline 6 & Severe & 2016-02-17 & 2016-06-01 & 3.14 & $\mathrm{HA} / \mathrm{HA}$ & $\mathrm{F}$ & 2014-08-18 & $2015-10-22$ \\
\hline 7 & Profound & 2015-12-11 & 2016-09-07 & 8.26 & $\mathrm{HA} / \mathrm{HA}$ & M & 2015-02-07 & 2015-10-05 \\
\hline 8 & Severe & 2016-05-07 & $2016-12-23$ & 7.16 & $\mathrm{HA} / \mathrm{HA}$ & $\mathrm{F}$ & 2016-03-09 & 2016-09-28 \\
\hline 9 & Profound & 2015-07-13 & 2016-07-29 & 12.16 & $\mathrm{Cl} / \mathrm{Cl}$ & M & $2015-04-20$ & $2016-01-26$ \\
\hline 10 & Moderate & 2016-07-06 & 2016-11-04 & 3.28 & $\mathrm{HA} / \mathrm{HA}$ & $\mathrm{F}$ & $2014-12-28$ & 2016-01-14 \\
\hline 11 & Moderate & 2015-08-14 & 2017-04-13 & 20.9 & $\mathrm{HA} / \mathrm{HA}$ & $F$ & 2014-04-20 & 2016-01-26 \\
\hline 12 & Severe & 2018-11-01 & $2019-02-25$ & 3.24 & $\mathrm{HA} / \mathrm{HA}$ & $F$ & 2014-09-17 & $2015-10-20$ \\
\hline 13 & Moderate to severe & 2016-03-01 & 2016-09-29 & 6.28 & $\mathrm{HA} / \mathrm{HA}$ & $\mathrm{F}$ & 2014-08-16 & 2015-11-15 \\
\hline 14 & Moderate & 2015-11-09 & 2016-07-08 & 7.29 & $\mathrm{HA} / \mathrm{HA}$ & $F$ & 2015-01-18 & 2015-10-05 \\
\hline 15 & Profound & 2014-07-20 & 2015-06-30 & 11.1 & $\mathrm{Cl} / \mathrm{Cl}$ & M & 2014-09-03 & 2015-09-14 \\
\hline 16 & Profound & 2016-12-11 & 2017-04-13 & 4.2 & $\mathrm{HA} / \mathrm{HA}$ & M & 2014-02-17 & $2015-11-30$ \\
\hline 17 & Profound & $2015-12-30$ & 2016-07-20 & 6.2 & $\mathrm{HA} / \mathrm{HA}$ & $\mathrm{F}$ & $2015-03-23$ & $2015-12-30$ \\
\hline 18 & Profound & 2014-12-08 & $2015-12-24 / 2016-01-28$ & $12.16 / 13.2$ & $\mathrm{HA} / \mathrm{Cl}$ & M & 2014-02-07 & 2016-02-25 \\
\hline 19 & Profound (unilateral) & $2014-10-27$ & 2015-07-30* & - & None & M & $2014-10-24$ & $2015-10-27$ \\
\hline 20 & Severe & $2012-01-20$ & 2016-05-31 & 52.11 & $\mathrm{HA} / \mathrm{HA}$ & $F$ & 2013-12-09 & $2015-12-26$ \\
\hline 21 & Profound & 2016-03-19 & 2016-08-18 & 4.29 & $\mathrm{HA} / \mathrm{HA}$ & $\mathrm{F}$ & $2015-02-24$ & 2015-10-05 \\
\hline 22 & Mild & 2015-03-31 & $2015-09-17^{*}$ & - & None & M & $2015-02-12$ & 2015-10-05 \\
\hline 23 & Severe & $2017-02-27$ & 2017-09-01 & 6.4 & $\mathrm{HA} / \mathrm{HA}$ & $\mathrm{M}$ & 2015-07-18 & $2016-01-29$ \\
\hline 24 & Mild & $2014-04-29$ & $2015-10-08^{*}$ & - & None & $F$ & 2015-02-08 & 2015-10-05 \\
\hline 25 & - & - & - & - & - & $\mathrm{M}$ & 2014-08-16 & 2015-10-18 \\
\hline 26 & - & - & - & - & - & $F$ & 2014-09-21 & 2015-10-22 \\
\hline
\end{tabular}

sample consists of four structured processes using dolls, balloons, bubbles, and snacks in the bottle; and two unstructured processes which could be adapted differently by experts according to the children's responses and situations using books, role-playing, parts of the body, and some objects. All the statistical analyses were performed using SPSS version 25.0 software. A general linear model of analysis of variance (ANOVA) was used. Specifically, the statistical analysis was designed for measuring variables repeatedly, setting within-subject as independent variables, and applying repeated ANOVA. A probability value of less than 0.05 was considered statistically significant.

\section{RESULTS}

\section{Production, comprehension, and action-gesture of the K M-B CDI evaluation}

When the NH and HL groups were compared at the same age, the performances of production and action-gesture were significantly better in the NH group $\left(F_{(1,90)}=13.269, p<.05, F_{(1,62)}=4.215\right.$, $p<.05)$. Specifically, the production of expressive language was significantly higher in $\mathrm{NH}$ groups at 19-24 months, and comprehension of receptive language and action-gesture scores were slightly better in the NH groups in most of the age groups, but without statistical significance on average. Since the children with NH and HL at 4-6 months could not produce consonants and vowels, the data 
analysis started from 7-months-old. When HA of the HL group was compared to the $\mathrm{NH}$ group, the production of expressive language was similar between the two groups until 15 months. After 16 months of age, the production of expressive language for the $\mathrm{NH}$ group showed better scores than that for the HL group. However, the HL group showed significantly better performances for actiongesture and comprehension of receptive language at 7-9 months and at 19-24 months. When CA and HA were compared for the HL group, the production of expressive language did not show any difference in all month periods. However, the comprehension of receptive language was significantly better in HA at 7-9 months and at 1924 months, and the action-gesture score was also better in HA at 7-9 months. When the performances were compared within the subjects, the comprehension of receptive language and action-gesture in $\mathrm{K}$ M-B CDI showed better performance as the intervention progressed $[(F=12.940, p<.05),(F=3.841, p<.05)]$ (Figure 1).

\section{Receptive and expressive languages of the SELSI evaluation}

When the NH and HL groups were compared at the same age, the scores for both receptive and expressive languages were signifi- cantly better in the NH group than in the HL group $\left(F_{(1,106)}=17.347\right.$, $\left.p<.05, F_{(1,106)}=35.551, p<.05\right)$. While the receptive language scores were significantly better only at 4-6 months and 7-9 months, the expressive language scores were significantly better at 4-6 months, 7-9 months, 16-18 months, and 19-24 months in the NH group. When HA of the HL group was compared to the NH group, significantly better performance of receptive language was shown for the HL group at 7-9 months. But better performance for expressive language was shown after 13 months for the $\mathrm{NH}$ group without a statistical significance. When CA and HA were compared for the HL group, both receptive and expressive languages showed significantly better scores in HA $\left(F_{(1,73)}=0.580, p<.05, F_{(1,73)}=11.036, p<.05\right)$. Specifically, significantly better receptive and expressive language scores were found from 4 to 9 months in HA. When the performances were compared within the subjects, receptive and expressive language in SELSI showed better performance as the intervention progressed $[(F=5.641, p<.05),(F=4.171, p<.05)]$ (Figure 2$)$.

\section{Social, speech, and symbolic scores of the CSBS DP checklist}

When the NH and HL groups were compared at the same age,

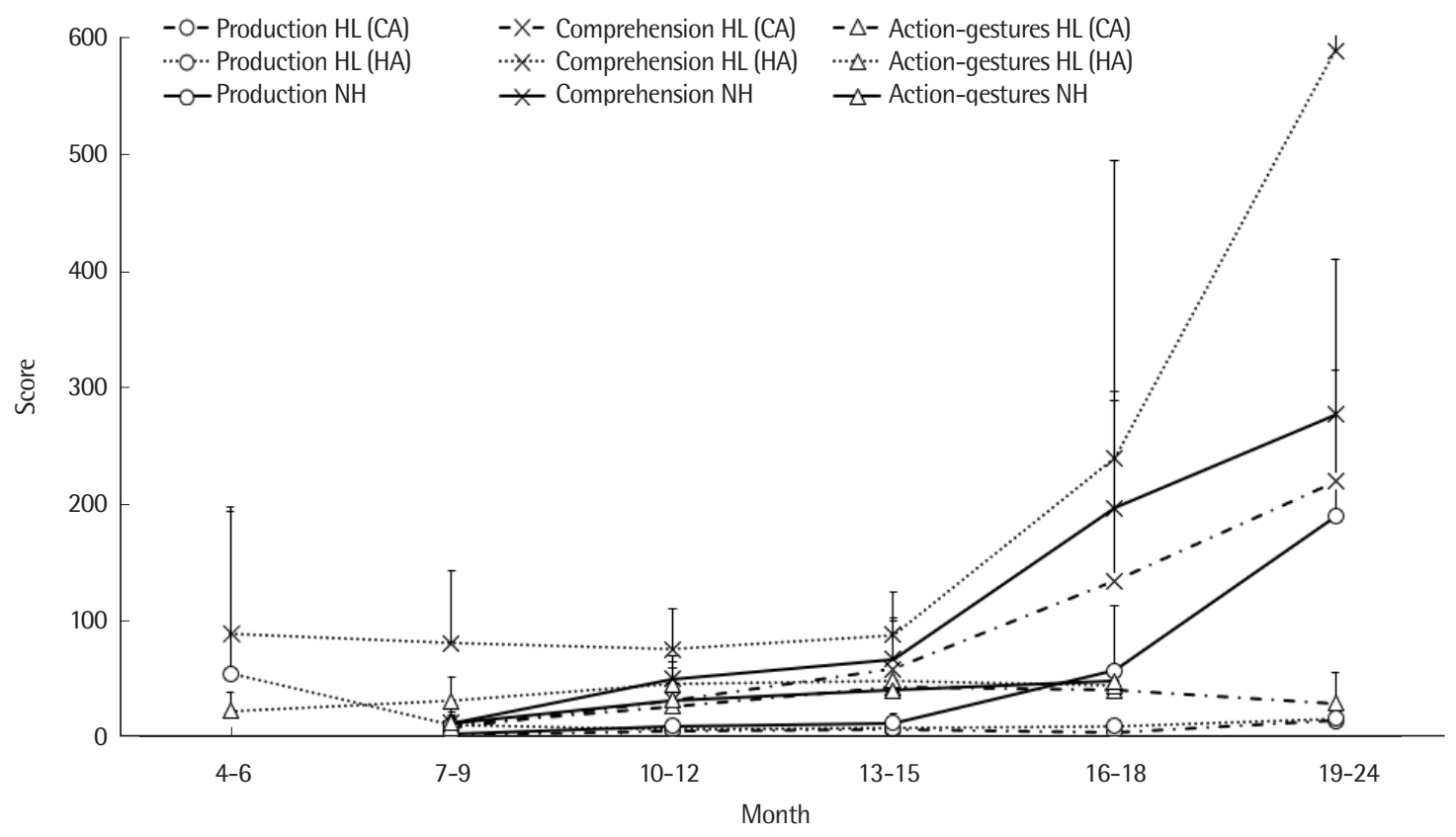

Figure 1. Plots of average scores for K M-B CDI. Circles (O) describe the scores of production, crosses $(X)$ describe the scores of comprehension, and triangles $(\triangle)$ describe the scores of action-gesture. Solid lines express the scores of normal hearing (NH) group, dotted lines express the scores of hearing loss (HL) group in hearing ages $(\mathrm{HA})$, and broken lines express the scores of $\mathrm{HL}$ group in chronological ages (CA). 


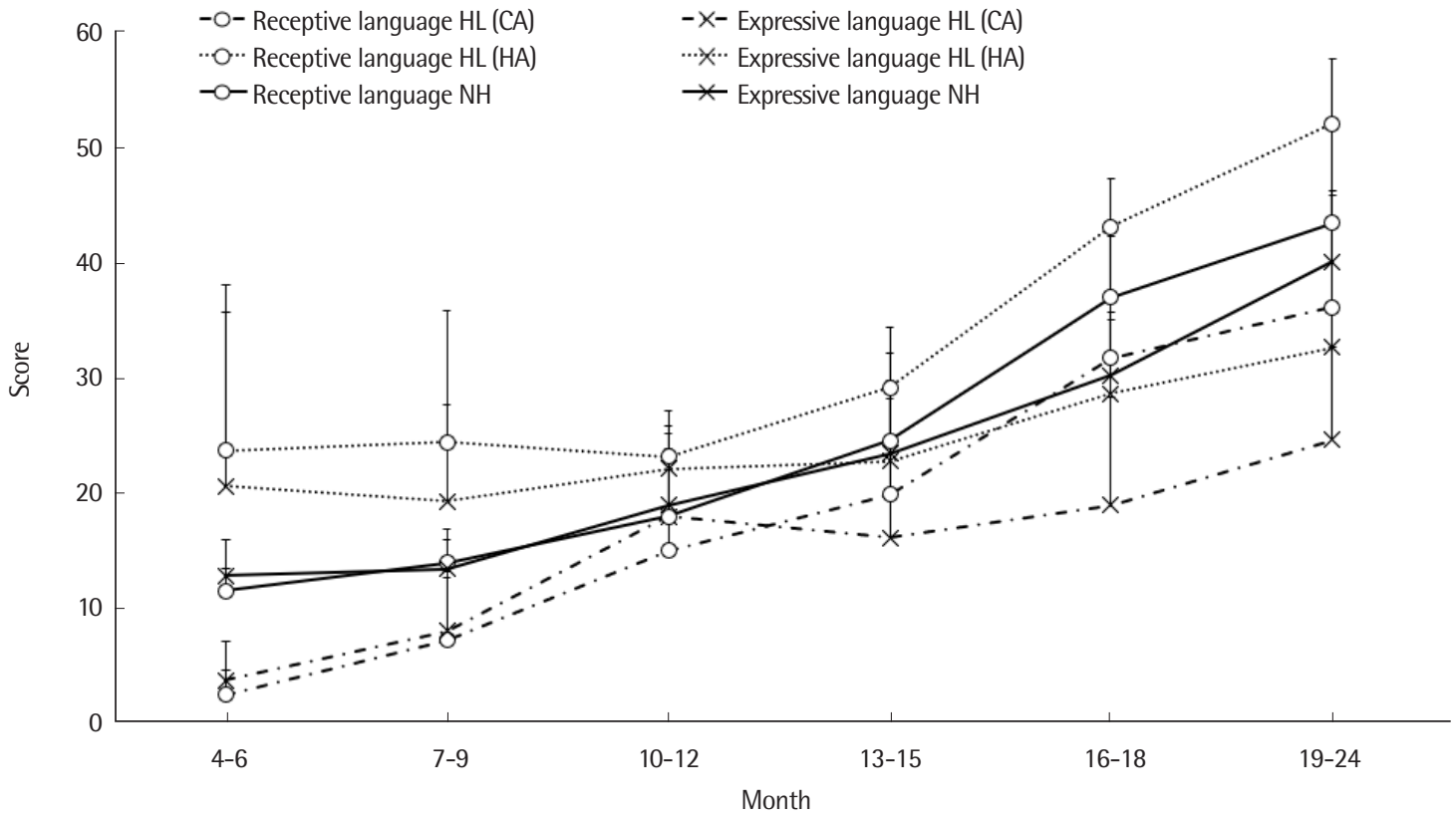

Figure 2. Plots of average scores for SELSI. Circles (O) describe the scores of receptive language, and crosses (X) describe the scores of expressive language. Solid lines express the scores of the normal hearing $(\mathrm{NH})$ group, dotted lines express the scores of the hearing loss $(\mathrm{HL})$ group in hearing age (HA), and broken lines express the scores of the $\mathrm{HL}$ group in chronological age (CA).

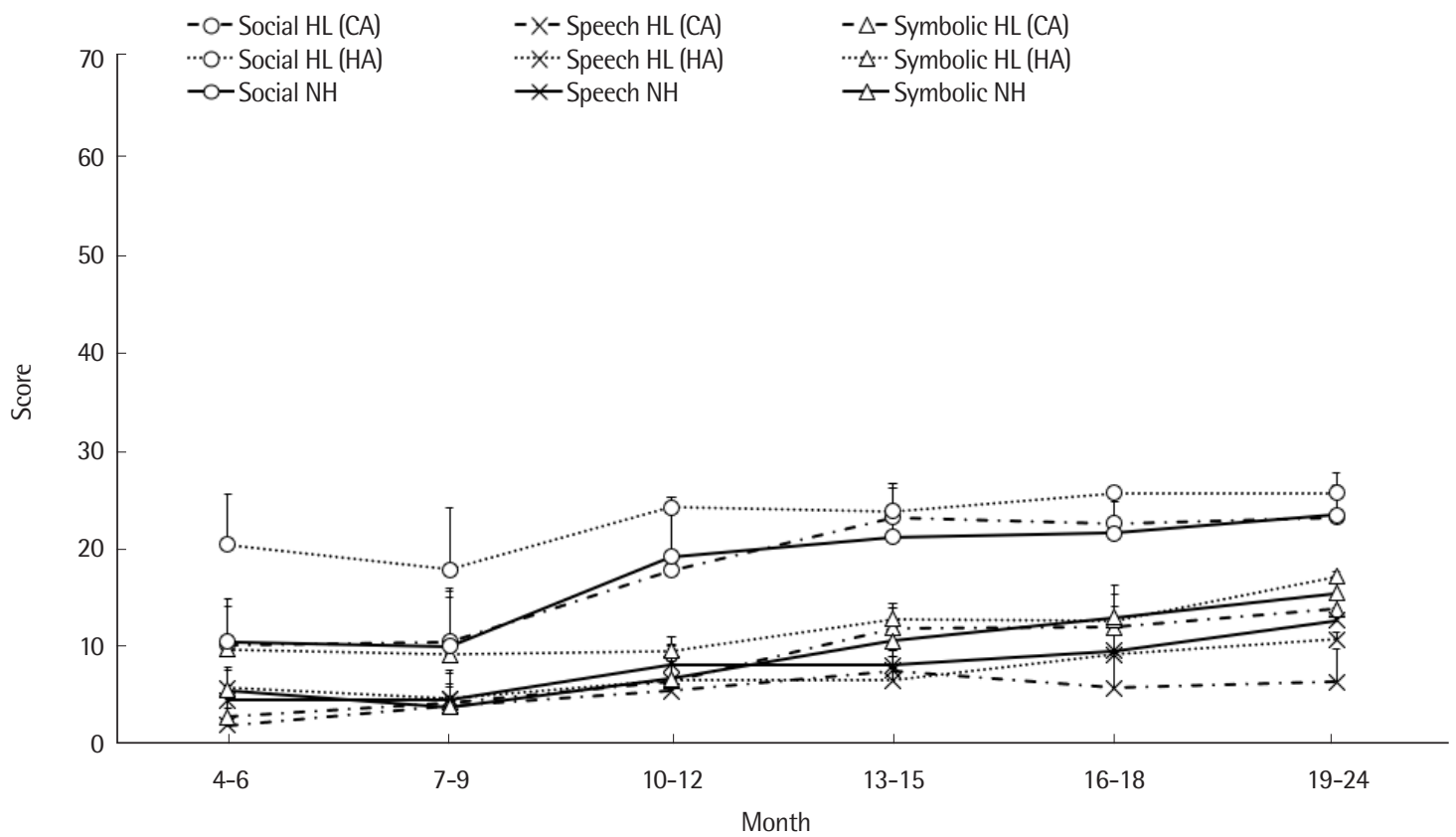

Figure 3. Plots of average scores for the CSBS DP checklist. Circles $(O)$ describe the social scores, crosses $(X)$ describe the speech scores, and triangles $(\triangle)$ describe the symbolic scores. Solid lines express the scores of the normal hearing (NH) group, dotted lines express the scores of the hearing loss ( $\mathrm{HL}$ ) group in hearing ages (HA), and broken lines express the scores of the $\mathrm{HL}$ group in chronological ages (CA).

the speech and symbolic scores were significantly better in the $\mathrm{NH}$ group $\left(F_{(1,89)}=34.167, p<.05, F_{(1,89)}=7.533, p<.05\right)$. The NH group showed significantly better speech scores from 16 to 24 months.
However, the social score showed no significant difference between the two groups. When HA of the HL group was compared to the $\mathrm{NH}$ group, the social and symbolic scores were better in the HL 


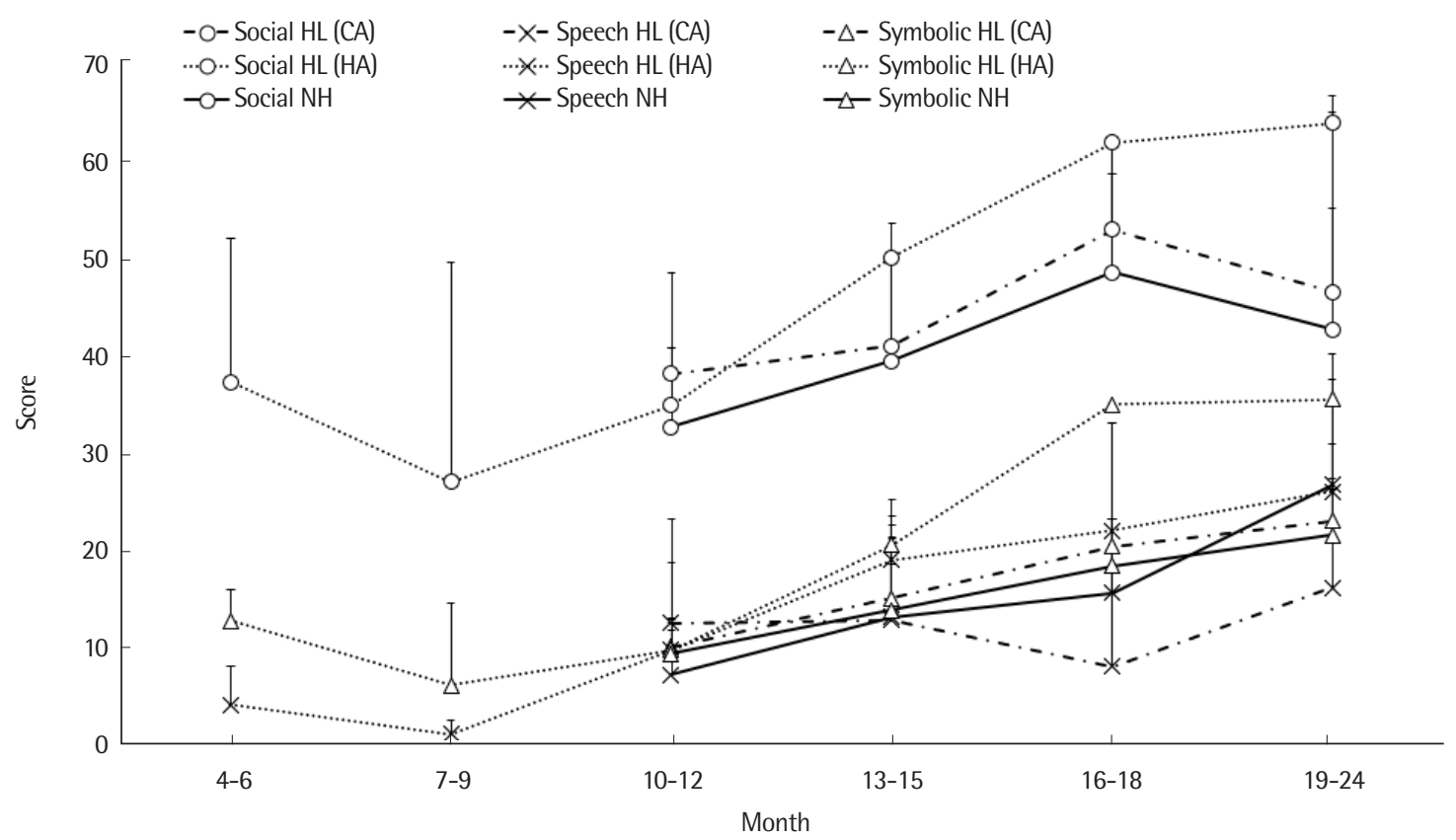

Figure 4. Plots of average scores for the CSBS DP behavior sample. Circles (O) describe the social scores, crosses $(X)$ describe the speech scores, and triangles ( $\triangle$ ) describe the symbolic scores. Solid lines express the scores of the normal hearing (NH) group, dotted lines express the scores of the hearing loss (HL) group in hearing age $(\mathrm{HA})$, and broken lines express the scores of the $\mathrm{HL}$ group in chronological age (CA).

group than in the NH group significantly at 4-6 months, at 10-12 months, and at 13-15 months. However, the speech score of the $\mathrm{NH}$ group at 19-24 months was significantly better than that of the HA of the HL group. When CA and HA were compared for the HL group, the HA showed significantly better social scores with a statistical significance $\left(F_{(1,63)}=6.248, p<.05\right)$ and better speech and symbolic scores without a statistical significance. The HA showed significantly better social and symbolic scores from 4 to 9 months and significantly better speech scores at 4-6 months. When the performances were compared within the subjects, the speech scores of the CSBS DP checklist showed better performance as the intervention progressed $(F=4.940, p<.05)$ (Figure 3).

\section{Social, speech, and symbolic scores of the CSBS DP behavior sample}

When the NH and HL groups were compared at the same age, the social and symbolic scores tended to be better in the HL group but without a statistical significance. There was no significant difference in the speech score between the two groups at 13-15 months; but after 16 months, the NH group showed a better score. When $\mathrm{HA}$ of the HL group was compared to the NH group, the social, speech, and symbolic scores were better in HA of the HL group. Specifically, the HA of the HL group exhibited a significantly better social score at 19-24 months. When the CA and the HA were compared for the HL group, the HA showed better performance for the social, speech, and symbolic scores, except for 10-12 months, without a statistical significance. Because the CSBS DP behavior sample was composed of the evaluation age from 12 months, the data under 12 months were not possible to compare. When the performances were compared within the subjects, the scores demonstrated better performance as the intervention progressed without statistical significance (Figure 4).

\section{CONCLUSION}

Early identification and intervention of children with HL is crucial. Children who were identified as having HL and received treatment and intervention by 6 months of age showed significantly better receptive and expressive language abilities than children identified after 6 months of age (Yoshinaga-Itano, Sedey, Coulter, \& Mehl, 1998). Also, HA showed better performances than CA in four evaluation tools of this study, which proved the importance of 
starting intervention as early as possible. In addition, as the degree of family involvement was associated with positive results of early intervention (Kim \& Lee, 2017; Moeller, 2000), the style of AVT intervention was proven to be important by the result of this study.

The HL group did well at the social composite which focused on the assessment of non-verbal communication development in our study by showing higher scores than the NH group with the CSBS DP behavior sample. It is possible that non-verbal communication development using social and symbolic abilities was not affected by HL in the early stage. Thus, the importance of stimulation with non-verbal communication methods in this period should be encouraged. As various means of communication could supplement these abilities regardless of the children's hearing status, the limitation of the means for stimulation of children with HL should be ruled out. Rather, it is better to concentrate on meaningful interaction between children and parents or caregivers for developing cognitive and social abilities, as Lewis and Coates (1980) emphasized. Also, it was revealed that caregivers' leading interactions that directly required infants to behave and respond increased infants' language use opportunities and brought about positive effects on communicative behaviors for 18-24 months of age through a study using the K M-B CDI and SELSI (Kim \& Lee, 2017). Therefore, we recommend practicing meaningful interaction as much as possible and starting intervention which provides sufficient listening and speaking stimulation before directly developing speech production for children with HL.

When the corresponding age of the $\mathrm{NH}$ group and HA of the HL group were compared, the scores of comprehension and actiongesture measured by the K M-B CDI, receptive language measured by the SELSI, and social and symbolic composites measured by both the CSBS DP checklist and the behavior sample, the performance of the HL group in our study was better than that of the $\mathrm{NH}$ group. In the HL group, the HA demonstrated early communicative skills in the language developmental process better than the CA. Specifically, as they started to use hearing devices from 9 months after birth, the good performances in social ability and language acceptance in children with HA in our study were revealed. This result agreed with a previous study. It was reported that an infant with a congenital profound HL showed improvement in general language development screening tests including the SELSI, K M-B CDI, and CSBS DP tests after participating in an early intervention program from 9 to 12 months of age (Yoon, Kim, \& Park, 2016). These findings also showed the importance of early interventions for improving overall language development as previously reported (Rinaldi, Baruffaldi, Burdo, \& Caselli, 2013).

The good performances in language acceptance and social abilities of the HL group of this study were accomplished as a result of the early interventions which were initiated at the time of receiving the amplification devices and involve meaningful communication and concentration with mediating reinforcement for listening with the professionals and parents. The results of the study recorded similar or higher scores of the HL group in the production section of the K M-B CDI and speech composite section of CSBS DP behavior sample for the ages under 19 months proving the importance of providing meaningful stimulation to children with HL in the early stages of developing language expression. This might have reflected the effect of the scope of the test using simple words as in fact, the SELSI, which used complex words, showed lower scores in the HL group. Regarding the intervention effect, only simple and meaningful stimulations were significant due to insufficient expressions at this early age. We acknowledge the limitation of this study in regards to the fact that there may have been a shortage of data collection. Therefore, the effect of intervention could be further proved with sufficient material of this age in future studies. It is likely that frequent simple word stimulation with meaningful communication for children with HL would be effective for social and language development in the early-stages of language development (Ertmer et al., 2002). It was reported that lexical development appeared even before 24 months of age for children with severe to profound HL using CA (Park \& Pae, 2003) and the prelinguistic communicative gestures were closely related to later language development when tracking frequencies of deictic and pointing gestures with the CSBS DP and language ability at 24 months of age using the SELSI and K M-B CDI (Choi \& Lee, 2018). In conclusion, the developmental process under 24 months of age should not be overlooked for children with HL. The use of HA in addition to CA is strongly suggested for effective evaluation as the diagnosing $\mathrm{HL}$ and fitting for amplification devices is happening at earlier ages recently. 


\section{REFERENCES}

Choi, J. J., \& Lee, Y. (2018). Communicative gestures in prelinguistic periods as predictors of later language development in Korean toddlers. Communication Sciences \& Disorders, 23(1), 11-19.

Ertmer, D. J., Young, N., Grohne, K., Mellon, J. A., Johnson, C., Corbett, K., \& Saindon, K. (2002). Vocal development in young children with cochlear implants. Language, Speech, and Hearing Services in Schools, 33(3), 184195.

Fenson, L., Marchman, V. A., Thal, D. J., Dale, P. S., \& Reznick, J. S. (2007). MacArthur-bates communicative development inventories (CDIs). Baltimore: Paul H. Brookes Publishing Co., Inc.

Ha, S., \& Pi, M. (2018). Phonological characteristics of early lexicon in Korean-acquiring children. Communication Sciences \& Disorders, 23(4), 829844.

Kim, G., \& Lee, H. (2017). Effect of maternal linguistic input type on communicative behaviors and language ability of 18- to 24-month-old toddlers. Communication Sciences \& Disorders, 22(1), 1-13.

Kim, J., \& Yoon, J. (2016). Development of Korean aural rehabilitation for infants. Audiology and Speech Research, 12, S41-S46.

Kim, J., Yoon, J., Park, H., Park, K., \& Lee, J. (2017). The development of Korean infant vocal and articulatory development list. Audiology and Speech Research, 13(2), 141-160.

Kim, Y. T., Kim, K. H., Yoon, H. R., \& Kim, H. S. (2003). Sequenced Language Scale for Infants (SELSI). Seoul: Special Education Publishing.

Knoors, H., \& Marschark, M. (2014). Teaching deaf learners: psychological and developmental foundations. New York, NY: Oxford University Press.

Lee, Y., Lee, H., \& Choi, J. (2018). A study of validity and reliability of the CSBS DP behavior sample in Korean toddlers. Communication Sciences \& Disorders, 23(2), 539-548.

Lewis, M., \& Coates, D. L. (1980). Mother-infant interaction and cognitive development in twelve-week-old infants. Infant Behavior and Development, 3, 95-105.

Moeller, M. P. (2000). Early intervention and language development in children who are deaf and hard of hearing. Pediatrics, 106(3), e43-e43.

Northern, J. L., \& Downs, M. P. (2002). Hearing in children. Baltimore, MD: Williams \& Wilkins.
Pae, S., \& Kwak, K. C. (2011). Korean MacArthur-Bates Communicative Development Inventories (KM-B CDI). Seoul: Mindpress.

Park, H., \& Pae, S. (2003). Early expressive vocabulary fevelopment of Korean children with hearing impairment. Korean Journal of Communication \& Disorders, 8(1), 66-81.

Rinaldi, P., Baruffaldi, F., Burdo, S., \& Caselli, M. C. (2013). Linguistic and pragmatic skills in toddlers with cochlear implant. International Journal of Language \& Communication Disorders, 48(6), 715-725.

Soman, U. G., Kan, D., \& Tharpe, A. M. (2012). Rehabilitation and educational considerations for children with cochlear implants. Otolaryngologic Clinics of North America, 45(1), 141-153.

Theunissen, S. C., Rieffe, C., Netten, A. P., Briaire, J. J., Soede, W., Schoones, J. W., \& Frijns, J. H. (2014). Psychopathology and its risk and protective factors in hearing-impaired children and adolescents: a systematic review. JAMA Pediatrics, 168(2), 170-177.

Wetherby, A. M., \& Prizant, B. M. (2002). CSBS DP manual: communication and symbolic behavior scales developmental profile. Baltimore, MD: Paul H. Brookes Publishing.

Yang, Y., Park, S., Hong, Y., Lee, S., \& Yim, D. (2019). The phonological similarity pattern of words contributing to expressive vocabulary in 18- to 36-month-old toddlers. Communication Sciences \& Disorders, 24(3), 553564.

Yoo, H., \& Kim, J. (2018). Attachment parenting and auditory, language and cognitive rehabilitation. Audiology and Speech Research, 14(1), 11-22.

Yoo, H., Kim, D., \& Kim, J. (2019). Study of early intervention effect using Korean auditory, language, and cognitive rehabilitation for infants with hearing loss. Audiology and Speech Research, 15(2), 119-134.

Yoon, J., Kim, J., \& Park, H. (2016). Early auditory rehabilitation of an infant with unilateral profound hearing loss: a case study. Audiology and Speech Research, 12(2), 115-125.

Yoon, M. S. (2007). A qualitative study of the evaluation of communication abilities in the diagnosis of children with hearing impairment. Korean Journal of Communication \& Disorders, 12(3), 447-464.

Yoshinaga-Itano, C., Sedey, A. L., Coulter, D. K., \& Mehl, A. L. (1998). Language of early-and later-identified children with hearing loss. Pediatrics, 102(5), 1161-1171. 


\section{국문초록}

\section{생활연령과 듣기연령에 따른 건청 영유아와 난청 영유아의 초기 의사소통 기술 연구}

윤지영 ${ }^{1} \cdot$ 박혜진 $\cdot$ 이은성 $\cdot$ 유희순 ${ }^{1}$ 김진숙 ${ }^{3}$

'한림대학교 일반대학원 언어병리청각학과, ${ }^{2}$ 서울아산병원 이비인후과 언어청각재활실, ${ }^{3}$ 한림대학교 언어청각학부 및 청각언어연구소

배경 및 목적: 말, 언어 평가는 건청인과 난청인의 발달 과정을 확인하는데 중요한 역할을 한다. 본 연구는 건청과 난청 영유아의 초기 의사소통 기술 특성을 분석하고 이를 생활연령과 듣기연령에 따라 비교하고자 하였다. 방법: 4-56개월 사이의 건청 영유아 26명과 난청 영유아 24 명으로 총 50 명의 영유아와 부모를 대상으로 연구를 실시하였다. 검사도구로 한국판 맥아더-베이츠 의사소통 발달평가, 영유 아 언어발달검사, 의사소통 및 상징행동 척도: 발달 프로파일의 체크리스트와 행동 샘플을 사용하여 초기 의사소통 기술을 2-3개월마 다 정기적으로 평가하고 생활연령과 듣기연령으로 구분하여 분석하였다. 건청 영유아와 난청 영유아의 평균 생활연령은 각각 17 과 19 개월이었으며 난청 영유아의 평균 듣기연령은 13 개월이었다. 난청 영유아는 평균적으로 생후 9 개월부터 청각 보조기기의 사용을 포함 한 적절한 중재를 받기 시작하였다. 결과: 듣기연령으로 분석했을 때 난청 영유아 집단은 건청 영유아 집단보다 일반적으로 높은 점수 를 보였다. 난청 영유아 집단은 생활연령을 기준으로 한 경우보다 듣기연령을 기준으로 하였을 때 모든 평가 결과에서 유의하게 높은 점 수를 나타냈다 $(p<.05)$. 논의 및 결론: 결론적으로 난청 영유아의 초기 의사소통 기술 향상을 위한 청각 증폭기기 착용과 적절한 조기 중재의 효과를 평가하고 분석할 때 난청 영유아의 우수한 수행능력 결과는 듣기연령 사용의 효율성을 시사하였다.

핵심어: 난청, 초기 의사소통 기술, 듣기연령, 생활연령

\section{참고문헌}

김규리, 이희란(2017). 어머니의 언어적 입력 유형이 18-24개월 유아의 의사소통 행동과 언어능력에 미치는 영향. Communication Sciences \& Disorders, 22(1), 1-13.

김영태, 김경희, 윤혜련, 김화수(2003). 영유아 언어발달검사(SELSI). 서울: 도서출판특수교육.

김진숙, 윤지은(2016). 영아의 조기 청능재활 프로그램 개발. Audiology and Speech Research, 12(0), S41-S46.

김진숙, 윤지은, 박혜진, 박경연, 이지현(2017). 국내 영아의 발성 및 조음발달 목록 개발. Audiology and Speech Research, 13(2), 141-160.

박혜진, 배소영(2003). 청각장애 유아의 어휘 발달. 언어청각장애연구, 8(1), 66-81.

배소영, 곽금주(2011). 한국판 맥아더-베이츠 의사소통 발달평가(K M-B CDI). 서울: 마인드프레스.

유희순, 김진숙(2018). 애착육아와 청각언어인지 재활. Audiology and Speech Research, 14, 11-22.

유희순, 김도균, 김진숙(2019). 청각장애 영유아의 청각언어인지재활(KARI) 을 이용한 조기 중재 효과 연구. Audiology and Speech Research, 15(2), 119-134.

윤미선(2007). 청각장애 아동의 진단과 평가 시 의사소통능력평가의 중요성에 관한 질적 연구. 언어청각장애연구, 12(3), 447-464.

윤지은, 김진숙, 박혜진(2016). 일측성 고심도 난청 영아의 조기청능재활 사례 보고. Audiology and Speech Research, 12(2), 115-125.

이윤경, 이효주, 최지은(2018). 한국판 표준화를 위한 'CSBS DP 행동샘플평가' 신뢰도 및 타당도 연구. Communication Sciences \& Disorders, 23(2), 539-548.

양윤희, 박수연, 홍예은, 이수연, 임동선(2019). 18-36개월 유아의 표현어휘력에 기여하는 단어의 음운유사도 양상. Communication Sciences \& Disorders, 24(3), 553-564.

최진주, 이윤경(2018). 언어이전 시기의 의사소통적 몸짓 사용이 24개월 언어발달에 미치는 영향에 관한 종단연구. Communication Sciences \& Disorders, 23(1), 11-19.

하승희, 피민경(2018). 12-30개월 아동의 초기 어휘에 나타난음운 특성. Communication Sciences \& Disorders, 23(4), 829-844. 


\section{ORCID}

윤지영(제1저자. 대학원생 https://orcid.org/0000-0002-5561-3205); 박혜진(공동저자. 언어재활사 https://orcid org/0000-0003-4467-1490); 이은성(공동저자, 대학원생 https://orcid.org/0000-0001-6525-3533); 유희순(공동저자, 대학원생 https://orcid.org/0000-0002-5262-3264); 김진숙(교신저자, 교수 https://orcid.org/0000-0003-3440-2393) 